\title{
"Arab Spring and COVID-19: Ex post facto examination of the Lebanese banking sector (the contemporary stakeholder analysis)"
}

\begin{tabular}{|c|c|}
\hline \multirow{3}{*}{ AUTHORS } & Rania Itani (i) https://orcid.org/0000-0002-9756-1386 \\
\hline & Muhammad Azeem id https://orcid.org/0000-0002-3264-6231 \\
\hline & Nawazish Mirza id https://orcid.org/0000-0003-4265-9519 \\
\hline ARTICLE INFO & $\begin{array}{l}\text { Rania Itani, Muhammad Azeem and Nawazish Mirza (2020). Arab Spring and } \\
\text { COVID-19: Ex post facto examination of the Lebanese banking sector (the } \\
\text { contemporary stakeholder analysis). Banks and Bank Systems, 15(4), 121-136. } \\
\text { doi:10.21511/bbs.15(4).2020.11 }\end{array}$ \\
\hline DOI & http://dx.doi.org/10.21511/bbs.15(4).2020.11 \\
\hline RELEASED ON & Tuesday, 15 December 2020 \\
\hline RECEIVED ON & Sunday, 13 September 2020 \\
\hline ACCEPTED ON & Tuesday, 01 December 2020 \\
\hline JOURNAL & "Banks and Bank Systems" \\
\hline ISSN PRINT & $1816-7403$ \\
\hline ISSN ONLINE & $1991-7074$ \\
\hline PUBLISHER & LLC "Consulting Publishing Company "Business Perspectives" \\
\hline FOUNDER & LLC "Consulting Publishing Company "Business Perspectives" \\
\hline
\end{tabular}

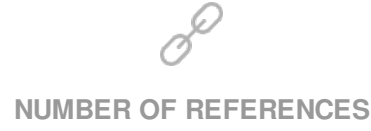

54
NUMBER OF FIGURES

9

\section{ニニ:-}

NUMBER OF TABLES

2

(C) The author(s) 2022. This publication is an open access article. 


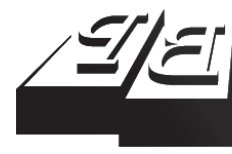

BUSINESS PERSPECTIVES

(O)

LLC "CPC "Business Perspectives"

Hryhorii Skovoroda lane, 10,

Sumy, 40022, Ukraine

www.businessperspectives.org
Received on: $13^{\text {th }}$ of September, 2020 Accepted on: $1^{\text {st }}$ of December, 2020 Published on: $15^{\text {th }}$ of December, 2020

() Rania Itani, Muhammad Azeem, Nawazish Mirza, 2020

Rania Itani, DBA, Assistant Professor, American University in the Emirates, Dubai, UAE. (Corresponding author)

Muhammad Azeem, Ph.D., Assistant Professor, American University in the Emirates, Dubai, UAE.

Nawazish Mirza, Ph.D., Associate Professor, Excelia Business School, La Rochelle, France.

\section{ARAB SPRING AND COVID-19: EX POST FACTO EXAMINATION OF THE LEBANESE BANKING SECTOR (THE CONTEMPORARY STAKEHOLDER ANALYSIS)}

\begin{abstract}
The purpose of this study is to examine the potential of Lebanese banks to address the economic challenges posed by COVID-19. These banks faced the disturbances of the 2011 Arab Spring, and these two crises have resulted in similar economic conditions, leading to an assessment of how Lebanese banks are dealing with the pandemic-led challenges. Exploratory analysis revealed the common features in the two events, and confirmatory analysis examined the hypotheses underlying a theoretical framework. Triangulation of qualitative and quantitative data helped to scrutinize the two events. Content analysis of data collected from semi-structured interviews with seven senior banking professionals confirms that the Lebanese banking sector's experience gained during the Arab Spring is a valuable asset for bankers, the Banque du Liban (BDL), and the government, which can be used to anticipate and deal with the COVID-driven economic crisis. The study finds three key moderating factors: trust deficit, inherited characteristics of the economy, and fiscal and monetary policy. Most of these conditions are permanent in nature and require long-term planning. As this research was conducted before the catastrophe caused by the August 2020 Beirut explosion, no aspects of the financial consequences to the Lebanese banking sector and economy resulting from this immerse shock are included.
\end{abstract}

Keywords pandemic, economy, Lebanese bank, trust deficit, public policies

\section{JEL Classification G01, G21, G28}

\section{INTRODUCTION}

This study has its roots in the first spark of the Arab Spring, which started in Tunisia in December 2010 and rapidly spread to many Arab countries. The cost to the large population of the Middle East countries can be seen in both economic and psychological terms. A common cause identified in several studies was people's mistrust and disappointment in respective elite governments, unable to provide economic stability (Kireçci, 2020; Boucekkine et. al., 2016; Echevarría, \& García-Enríquez, 2019). On the other hand, the COVID-19 pandemic has shaken the entire world and transformed every facet of society (Iacus et. al., 2020; Zenker \& Kock, 2020; Sigala, 2020; Saha et. al., 2020; Liu \& Chang, 2020; Sheth, 2020). It will have a domino effect, and coming out of the immediate pandemic does not mean that the crisis is over. Less developed economies (LDC) are vulnerable and will be more affected by the pandemic. Countries like Lebanon, characterized by persistent political and economic turmoil, are in jeopardy. The Lebanese banking sector has gone through the global financial crises of 2008 and the Arab Spring of 2011, and the lessons learned from these events have been driving the financial and business policies of 
commercial banks. The term Arab Spring in this study aims to distinguish a specific period known for the socio-political changes and the economic turmoil in the Arab world, and specifically Lebanon. However, it is important to note that the paper does not cover any political aspects related to the Arab Spring period; instead it is used as a reference period to gain the common ground between the two events in terms of economic crises, and to understand how previous experience is relevant to the current challenges of the banking sector. The economic threat from COVID-19 has raised the question: Can Lebanese banks rely on the experience learned from the Arab Spring to deal with the COVID-19 crisis? The literature on the Arab Spring provides no information that can help in mapping the two situations, Arab Spring and COVID-19, as there is yet no comparable research on COVID-19. Therefore, the purpose of this study is to find the answer to the question: Can Lebanese banks rely on the experience learned from the Arab Spring to deal with the COVID-19 crisis? To answer this question, it is important to examine the literature to further clarify the case and to develop a theoretical framework.

\section{LITERATURE REVIEW}

Using the search term "Arab Spring", 1,673 Englishlanguage articles published from 2012 to 2020 were retrieved from the Scopus database. The following articles were excluded: documents with fewer than 100 citations; those on political, psychological, and non-economic issues; and those focusing on regions outside the Arab world. Finally, only 29 articles were explored. Most of the studies were written in the context of Tunisia and Egypt (El-Haddad, 2020), but further examination revealed differences due to lo$\mathrm{cal}$ and national conditions. According to Shehadeh and Lai (2020), it appears that the crises were the result of movements seeking religious supremacy. The over-emphasis on Western ideals reflected through public policies without understanding the actual cultural structure and epistemological traditions led to skewed progress in society, preventing most of the population from taking advantage of the system (Lightfoot, 2015). The forces protecting the existing status quo had a prolonged impact on the economy (Aras \& Falk, 2016). According to Malec et al. (2013), the inherent characteristics of the economies also coexisted with the new phenomena, fueling destabilization. For example, Al-Rawashdeh et al. (2016) highlighted the mediating factors, including corruption, lack of democracy, military spending, and foreign funds outflow, which led to negative growth in the oil- and mineral-rich countries of the MENA region. Similarly, Devarajan (2020) identified the term "inequality puzzle" to explain that despite favorable income inequality measures, the subjective well-being measures in Arab countries were relatively low, falling sharply during the Arab Spring. The post-Arab Spring economic situation offers real evidence of the dominance of such permanent features in national economies. Falk (2020) predicts that it is likely that the Middle East will continue to experience chaos as a result of such inherited factors, unless a social contract for economic uplift is written between states and the people (Rougier, 2026). The revolution began in Tunisia, and the impact in terms of loss in GDP during 2011, 2012 and 2013 was 5.5\%, 5.1\% and 6.4\%, respectively (Matta et al., 2019). Investment volume was the real cause of the adverse impact on economies during the Arab Spring (Helmy, 2013). The size of the shadow economy also reduced the impact of policy measures taken by governments, and this should be controlled by promoting liberal economic policies (Farzanegan, 2020). People's trust and tolerance were shaken during the Arab Spring, and that needed to be addressed to control the influence of government measures on the economy. The economic response also depends on the level of spending by the public and private sectors. Political unrest brings instability and discourages revenue sources such as tourist income (Lafferty \& Youssef, 2015). Competition is an important mediating factor, as it determines banks' liquidity creation. Abraheem et al. (2020) revealed that liquidity creation was negatively related to competition before the Arab Spring and positively related to it afterwards; that is, the stability of a bank reduces liquidity creation. In short, the factors contributing to the economic crisis during the Arab Spring include the socio-political systems of Middle East countries, people's mistrust of governments, skewed economic progress, the status quo of the elite, the shadow economy, investment levels, and levels of public spending (Gibson, 2020).

The two situations - Arab Spring and COVID-19 need to be examined at the structural level. The former led to economic crises in the regions affected by revolution, while the latter is a health-related crisis, 
although its immediate impact is also economic recession (Wells et. al., 2020; Goffman, 2020; Brown \& Rocha, 2020; Nzediegwu, 2020; Saha et. al., 2020; Al-Awadhi et. al.; Qian \& Fan, 2020; Kadoya et, al., 2020). According to the WHO (2020), coronaviruses are defined as a "large family of viruses that may cause illness in animals or humans. The most recently discovered coronavirus infectious disease is known as COVID-19." As of May 14, 2020, the WHO reported the total number of confirmed cases to be above four million $(4,218,212)$, and the confirmed deaths 290,242 worldwide. The total population of Lebanon is $6,825,445$, and according to WHO's statistics, there were 878 confirmed cases of COVID-19 in the country, and 26 deaths, from February 21 to May14. Although the conditions in Lebanon were not very serious compared to the rest of the world, the country could not be separated from the global economic impact of COVID-19.

In 2019, the real GDP of Lebanon was reported as USD 40.16 billion, compared to the previous year's 42.56 billion. The GDP growth rate was a negative $5 \%$, equal to the GDP per capita growth rate. Inflation was reduced from $6 \%$ in 2018 to $3 \%$ in 2019. The interest rate in 2019 was reported as $8 \%$ and in April 2020 as 6\%. The unemployment rate remained stable at $6 \%$. The Lebanese Central Bank (Banque du Liban or BDL) sets the interest rates for operating banks in line with its monetary policy. The exchange rate (USD/LBP) remained stable during 2010 to 2019 at around 1,500 , reflecting control from BDL over the Lebanese Pound through strict monetary policy measures (see Table 1). However, this figure dramatically collapsed in April-May 2020, where the exchange rate reached 3,700 , more than $50 \%$ weaker than the official peg. This means a huge devaluation of the currency in the informal market during the country's severest financial crisis.
The Lebanese banking sector, comprising over 60 licensed banks, has been well managed despite various economic challenges over the years. The onus for governance, resilience and well-functioning remains with BDL. The subprime crisis of 2008 led to policies to protect local banks from any significant negative impact. This was a notable achievement, since in most of the Middle Eastern banking sectors there was a major deterioration in performance, asset quality and capital. In Lebanon, the banking system saw sustained progress and development; it achieved extension of deposits during a period when global banking operations were encountering severe competition. The second major test was during the Arab Spring, and this time the Lebanese banking sector was affected by the exposure of banking operations in the most affected countries, mainly Syria, Egypt, Tunisia, and Libya. Table 2 includes the major financial indicators pertaining to Total Assets (TA), Total Loans (TL), Total Deposits (TD), CAR (Capital Adequacy Ratio), Average Spread, Total Doubtful Loans (TDL) and Total number of licensed banks.

Table 2. Overview of financial performance of Lebanese banks from 2014 to 2017

\begin{tabular}{|c|c|c|c|c|}
\hline $\begin{array}{l}\text { Financial Performance } \\
\text { Indicators }\end{array}$ & 2014 & 2015 & 2016 & 2017 \\
\hline Total Number of Licensed Banks & 71 & 69 & 67 & 65 \\
\hline $\begin{array}{l}\text { Total Assets of Banks (millions } \\
\text { of USD) }\end{array}$ & 176 & 186 & 241 & 258 \\
\hline Total Deposits (millions of USD) & 148 & 155 & 189 & 196 \\
\hline Total Loans (millions of USD) & 51 & 54 & 73 & 75 \\
\hline $\begin{array}{l}\text { Total Doubtful Loans (millions } \\
\text { of USD) }\end{array}$ & 1.8 & & 1.3 & 1.3 \\
\hline $\begin{array}{l}\text { Average Capital Adequacy Ratio } \\
(\mathrm{T} 1+\mathrm{T} 2) \%\end{array}$ & 14.6 & 15 & 16.5 & 16.8 \\
\hline Average Spread & 1.90 & 1.92 & 1.92 & 1.94 \\
\hline
\end{tabular}

Table 1. Economic outlook of Lebanon for 2009-2019

\begin{tabular}{|c|c|c|c|c|c|c|c|c|c|c|c|}
\hline Economic Indicators & 2009 & 2010 & 2011 & 2012 & 2013 & 2014 & 2015 & 2016 & 2017 & 2018 & 2019 \\
\hline GDP (2010 USD bln) & 35.6 & 38.4 & 38.7 & 39.7 & 41.2 & 42.2 & 42.3 & 43.0 & 43.4 & 42.5 & 40.1 \\
\hline GDP per capita (2010 USD) & $7,397.5$ & $7,761.6$ & $7,453.8$ & $7,179.1$ & $6,978.9$ & $6,753.6$ & $6,487.9$ & $6,411.9$ & $6,370.8$ & $6,214.3$ & $5,858.2$ \\
\hline GDP (current USD) & 35.4 & 38.4 & 39.9 & 44.0 & 46.9 & 48.1 & 49.9 & 51.2 & 53.1 & 54.9 & 53.3 \\
\hline GDP per capita (curr. USD) & $7,354.9$ & $7,761.6$ & $7,674.8$ & $7,950.7$ & $7,931.0$ & $7,686.2$ & $7,644.5$ & $7,629.8$ & $7,801.1$ & $8,024.8$ & $7,784.3$ \\
\hline GDP growth (annual \%) & 10.2 & 7.9 & 0.8 & 2.5 & 3.8 & 2.4 & 0.2 & 1.5 & 0.8 & -1.9 & -5.6 \\
\hline GDP per capita growth (\%) & 9.1 & 4.9 & -3.9 & -3.6 & -2.7 & -3.2 & -3.9 & -1.1 & -0.6 & -2.4 & -5.7 \\
\hline Inflation, consumer Pr. (\%) & 1.2 & 3.9 & 4.9 & 6.5 & 4.8 & 1.8 & -3.7 & -0.7 & 4.3 & 6.0 & 3.0 \\
\hline $\begin{array}{l}\text { Unemployment, total (\% of } \\
\text { total labor force) }\end{array}$ & 6.3 & 6.4 & 6.4 & 6.4 & 6.4 & 6.4 & 6.3 & 6.3 & 6.2 & 6.1 & 6.2 \\
\hline
\end{tabular}


Total assets increased from USD 176 million in 2014 to 258 million in 2017, although the number of banks was reduced from 71 to 65 owing to consolidation in the banking sector through mergers. Total deposits were augmented from 2014 to 2017 due to the increased volume of inwards remittances received from the Lebanese "Diaspora" living outside the country. Lending was on a rise with total loans increasing from 51 million in 2014 to 75 million in 2017. The sector maintained a high capital adequacy with a sustained spread across the years. The importance of the Lebanese banking sector lies in maintaining characteristics, including high liquidity and solid capital adequacy. In addition, it plays a key role in supporting the Lebanese economy by instantaneously supporting the public deficit, and enjoying an active private sector. Therefore, it is appropriate to understand how the banking sector handled the Arab Spring and the lessons that can be learned from this tumultuous episode.

\subsection{Moderating factors between COVID-19 and the economic crises}

The literature on the economic impact of COVID-19 was reviewed and based on the researchers' observations and limited data available during January-May 2020. 20,759 documents were identified from the Scopus database using the search term COVID-19. By applying query filters for open access articles written in English in the year 2020 in the fields of Economics and Finance, Social Sciences, and Business, the figure was reduced to 766. The final count of the articles included in this study was 54 . There was no research paper written exclusively on the Lebanese banking sector with reference to COVID-19. Therefore, the inductive approach has been adopted to gather evidence about moderators in the relationship between COVID-19 and the economic crises, from other closely related fields in business, commerce, and economics.

The literature was explored for three areas: Inherited characteristics of the economy, the trust deficit among people about government performance, and national fiscal and monetary policies. Many authors have highlighted the role of permanent features prevailing in less developed coun- tries that contributed to the impact of COVID-19 on their economies. The pandemic impact can be seen at response, recovery, and reset stages (Sigala, 2020). For the less developed countries, the inherent characteristics contribute to the crisis more than in developed countries (Nzediegwu \& Chang, 2020). For example, population size is one of the factors and it adds to the government-level difficulty in dealing with COVID-19 situations. These countries have a high rate of positive COVID-19 cases, posing a real threat to their already struggling economies, and exerting immense pressure on the small number of front-line paramedical staff and health missionaries (Sharma et al., 2020). Sectors including travel and tourism (Morakabati, 2020), transportation, stock markets, and trading are affected badly by the severe economic contraction, and if governments in these countries are unable to establish a proper policy framework, the problem is acute (Singh \& Neog, 2020). The case of local governments and NGOs is similar, and they are also expecting serious financial planning challenges for years to come (Maher et al., 2020). The banking sector is also characterized by inefficiencies. For example, Non-Performing Assets (NPA) hamper banks' performance (Gaur \& Mohapatra, 2020). According to Francis and Pegg (2020), the presence of corruption, money laundering, political instability, violence, and environmental devastation are persistent features of the informal sectors and co-exist with the formal sectors of the economy. These conditions are directly impacting government efforts to combat the pandemic. Forces of the status quo ante have found their interests only through the current setup, driven by the perceived institutional barriers that impede entrepreneurial action in existing organizations during crises (Fisher et al., 2020). The readjustment process has brought these polarized forces to the forefront, protecting their own interest. The role of these groups can be marginalized by cross-partisan consensus (Merkley et al., 2020). The COVID-19 pandemic has also had an economic impact on society by causing imbalance in the income and regional disparities, and families from the more affected COVID-19 regions have experienced greater income losses (Qian \& Fan, 2020). These differences are due to existing structural disparities based on individual education level, family income status, political affiliations, sector-level employment, and community/city size. People evalu- 
ate the country, the government, and its strategy during the crises based on the past performance in similar situations (Gopichandran et al., 2020). During the pandemic, the narrative of 'defensive pessimism' dominates, but the persistence of low public risk perceptions and low levels of compliance with government risk management measures bring to light the paradox of trust (Wong \& Jensen, 2020). The rapid spread of COVID-19 has also caused dramatic impacts on financial markets all over the world, and has created an unprecedented level of risk, causing investors to suffer significant losses in a very short period of time, leading to economies like the US implementing zero-percent interest rates and unlimited quantitative easing (QE), which has further escalated uncertainty in global financial markets (Zhang \& $\mathrm{Hu}, 2020)$. The banks with greater portfolio diversification potential are at lower risk than banks in the advanced economies (Hernandez et al., 2020). In the context of demographic classification, communities in rural areas need a more careful approach in dealing with the epidemic situation by critically developing an action plan, and strategies engaging human resources and equipment (Tran et al., 2020). During the period of COVID-19, the optimal hedge ratios have increased significantly due to the higher hedging costs (Akhtaruzzaman et al., 2020). Financial markets and banks (e.g. in the US) are expecting a slowdown in the new financial regulations, which have been another extension of the state-finance nexus since the global financial crisis of 2008 (Wójcik \& Ioannou, 2020). A study conducted on Canadian banks by Talbot and Ordonez-Ponce (2020) identified three types of banks' actions during COVID-19: sweeping actions, cautious actions, and wait and see. The study claims that although the Canadian banking system is among the best in the world, with the exception of three banks, it has done little for their stakeholders, clients, and communities. The role of financial policy makers is important to relax the pessimistic view on the fiscal tightening and allow banks to breathe with confidence (Heimberger, 2020). The investment decisions of fund managers during COVID-19 in terms of size and strategy have shifted in favor of low-risk options, as well as from high coronavirus cases to the smaller number of cases (Rizvi et al., 2020). Governments around the world are pushing hard to stimulate spending by introducing poverty-al- leviating packages to families of the victims and those who have lost their breadwinners or their jobs. Unfortunately, such blanket solutions are ineffective when applied to everyone indiscriminately (Kadoya et al., 2020a). Even spending on safer commodities has suffered (Ali et al., 2020). In anticipation of post-pandemic recovery, public policies need to be focused on more vulnerable and marginalized segments of populations. The inherited characteristics, trust deficit, and conservative fiscal and monetary policies can magnify the vulnerability of the economies of Arab countries, whose characteristics are largely similar to other LDCs.

Figure 1 explains the conceptual framework using two simple structures to understand the case built in this study. Models 1 and 2 represent the cases of Arab Spring and COVID-19, respectively. The outcome variables in the two models are the same, that is the economic crises. The ex post facto examination of the cases suggests that the two situations can be mapped if moderating factors in the two models are similar, and therefore it is possible that the preemptive policies or strategies applied to deal with the Arab Spring in Lebanon can be considered valid for the case of COVID-19.

The list of factors contributing to the COVID19-driven economic crises can readily be divided into three groups: Trust Deficit, Inherited Characteristics of the Economy, and Fiscal and Monetary policies. Figure 2 is an expansion of model 1 in Figure 1, showing the list of moderators. It guides the study to the next level and invites further exploration of the literature on COVID-19 to find if any alignment between the two models exists in terms of moderators.

Figure 3 shows a theoretical framework, explaining the moderating role of three variables on the path between COVID-19 and resulting economic crises. The framework explains that the impact of each moderator can change the nature of the relationship on the path. For example, the high level of trust deficit cannot help governments to take strict measures or even call for public support. Such support is only possible when the confidence level is high. Likewise, the economies with more positive inherited characteristics can face the pandemic more easily than struggling 

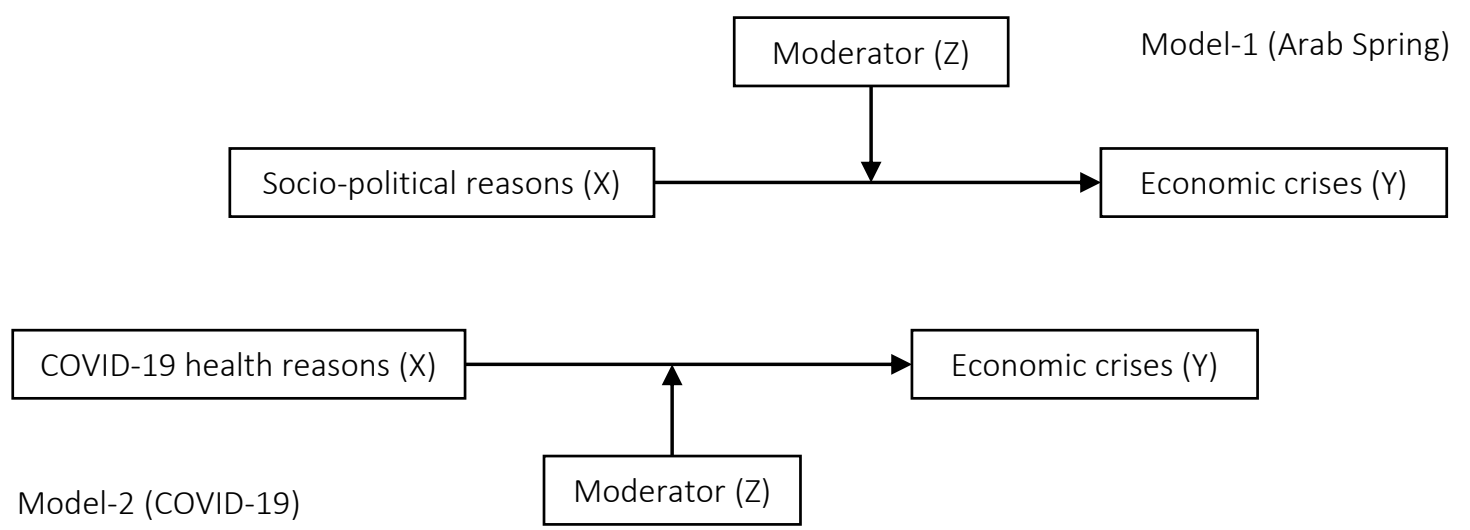

Figure 1. Simple models of Arab Spring and COVID-19

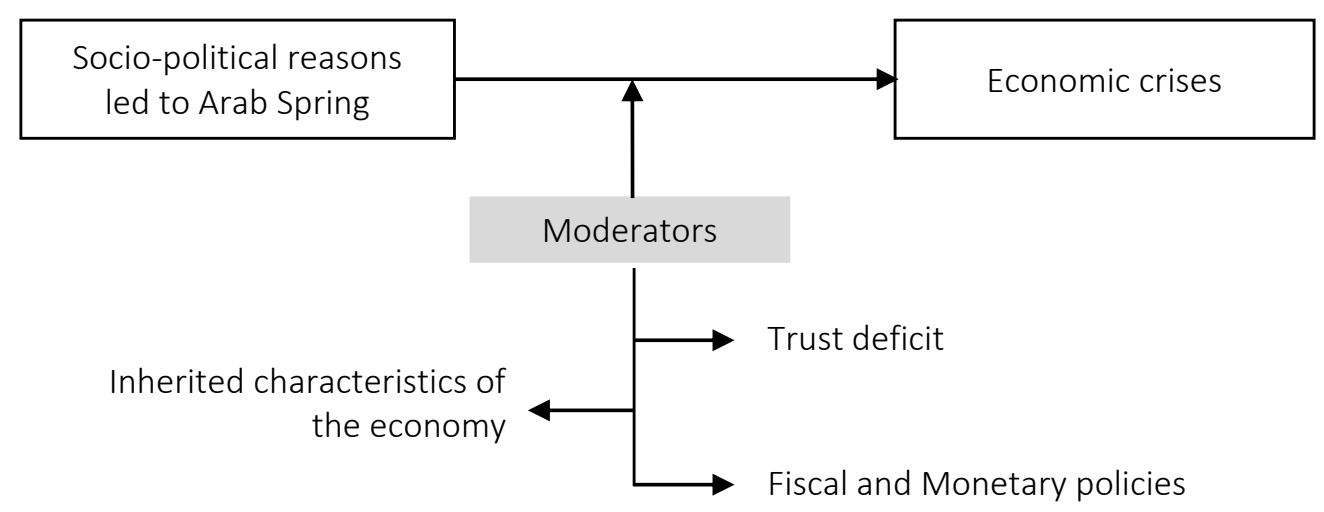

Figure 2. Moderation on the path between Arab Spring and economic crises

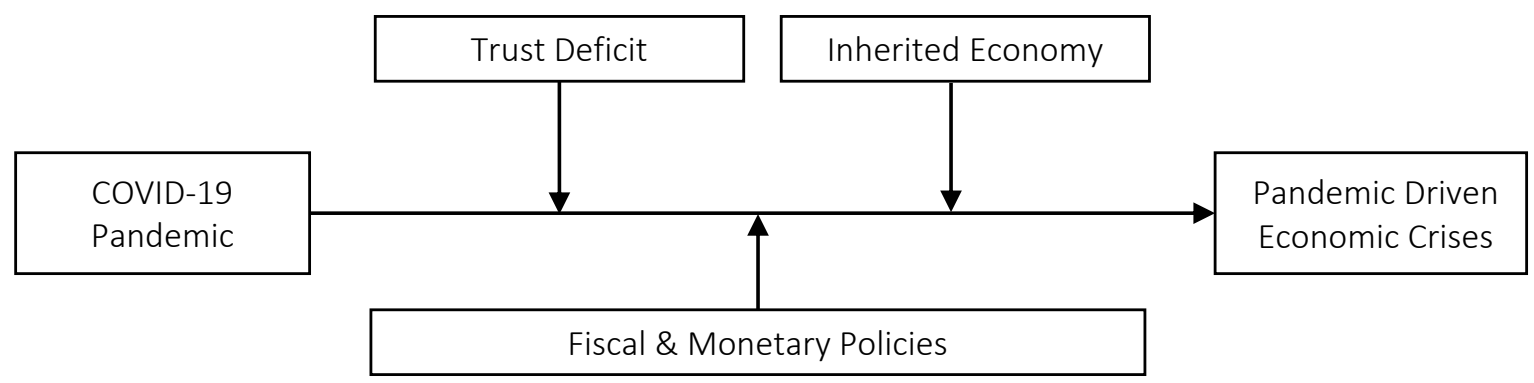

Figure 3. Theoretical framework (Moderation on the Path between COVID-19 and Economic Crises)

economies with poor indicators. Similarly, lib- The moderators identified in the Arab Spring and eral fiscal and monetary policies have a different the COVID-19 models are similar. This allows impact on the economy than conservative poli- hypothesizing that the Lebanese banks have the cies, depending on the stage of pandemic in the ability to deal with the COVID-19-driven ecocountry. nomic crises based on the experience from the 
Arab Spring. The following set of hypotheses is framed:

1) The degree of trust deficit is the same during COVID-19 and the Arab Spring in Lebanon.

2) The nature of the economy in terms of inherited characteristics has not significantly changed over the last decade.

3) The conservative fiscal and monetary policies that helped during the Arab Spring are also in place to support combating the COVID-19driven economic challenges.

4) The conditions during COVID-19 for economic reasons are not very different from those during the Arab Spring.

5) Lebanon's banking sector is able to deal with the current economic threat.

\section{METHODS}

The study is exploratory in nature and concerns the understanding of the moderators of the Arab Spring and COVID-19 identified in the literature. The study then uses a confirmatory approach to test the hypotheses. That is, the methodology is both inductive and deductive. The triangulation in the analysis enables a thorough examination of the two events based on both qualitative and quantitative data. The interview data was analyzed quantitatively through the content analysis technique in order to produce reliable and valid evidence to examine the relationship and research hypotheses (Krippendorff, 2004). The purposive or judgment sampling technique was adopted to reach the desired sample alongside the snowball approach, with the objective of taking advantage of the field specialist's knowledge about the sector. The selection of the sampling units was made with care so that the samples do not bias the answers to the research questions. Due to the common nature of the subject matter, a smaller sample size does not pose any threat to reliability, and therefore, assuming a 5\% significance level of the answers to the research question and an assumed probability of relevant instances $10 \%$, the sample size of seven is considered sufficient (Heimberger,
2020). To obtain face and content validity, the interview was simulated and a set of questions were sent to three experts in the field of banking and finance. The focus was set in the interviews to capture information about when and how bankers started to sense the Arab Spring in the Lebanese banking sector, and its immediate impact on the sector. Secondly, what factors were considered important in causing economic crises during the Arab Spring; and thirdly, how similar are the factors causing economic crises during the Arab Spring and COVID-19, and what was the status of Lebanese banks in terms of their potential to deal with the post-Covid-19 economic scenario?

\section{RESULTS}

The textual data from seven semi-structured interviews with experts from Lebanese banks was coded according to their distinctness and relevance to the study. The text was examined for propositional distinction with respect to the perception, recognition, justification, evaluation, and assurance of the interviewee. Three themes were derived from the text, based on the moderating variables identified in the theoretical framework: Trust Deficit, Inherited Characteristics of the Economy, and Fiscal and Monetary Policies. The confirmatory approach to the content analysis was adopted by predefining the themes and underlying categories and a list of possible terms. Each moderator was considered as a theme, and it was chained to the respective categories and terms found in the interview data. The categories can be considered as the latent variables during the visible manifestation in terms of sentences and sets of terms.

\subsection{Themes}

Following the thematic tree diagram shows the latent categories of trust deficit. Four categories were hypothesized based on the literature review: Fairness, Integrity, Competence, and Reliability (see Figure 4).

Each category can be considered as a latent construct with its manifestation through the group of terms derived from the statements extracted from the interview data. The arrows from the latent variable show that the terms act as the items or a 
Theme of Trust-Deficit

\begin{tabular}{|c|c|c|}
\hline Fairness & $\longleftrightarrow \begin{array}{l}\text { Economic rights } \\
\text { Haves and have nots }\end{array}$ & $\begin{array}{l}\text { Large population was unable to protect their economic rights } \\
\text { The class conflict was acute, and it was between haves and have nots }\end{array}$ \\
\hline Integrity & $\begin{array}{l}\text { Corruption } \\
\text { Dishonesty } \\
\text { Meet promises } \\
\text { Self-interests }\end{array}$ & $\begin{array}{l}\text { Corruption was high } \\
\text { Governments were dishonest } \\
\text { Unable to meet the promises } \\
\text { Leaders focus on their own self-interests }\end{array}$ \\
\hline Competence & $\begin{array}{l}\text { Ability } \\
\text { Incapable } \\
\text { Failing } \\
\text { Incorrectness }\end{array}$ & $\begin{array}{l}\text { People doubt the ability of government } \\
\text { Banks are not able to persistently support government in funding } \\
\text { the budget deficit } \\
\text { Incapable to serve the people } \\
\text { Fail to provide any solution to the unemployment } \\
\text { The information provided to people was incorrect } \\
\text { There are concerns for the currency stability }\end{array}$ \\
\hline Reliability & Inconsistency & $\begin{array}{l}\text { BDL is taking measures to restore the confidence of the bank } \\
\text { customers } \\
\text { The policies remain inconsistent over the years } \\
\text { Strikes and public protests are common and can force the } \\
\text { government to compromise } \\
\text { Loss of trust affects liquidity in the banking sector }\end{array}$ \\
\hline
\end{tabular}

Figure 4. Thematic construct of Trust Deficit

\section{Theme of Inherited Characteristics of the Economy}

\begin{tabular}{|c|c|c|}
\hline \multirow{5}{*}{ Shadow Economy } & Informal sector & The informal sector of the economy coexists with the formal sector \\
\hline & Black market & Black marketers remained active \\
\hline & & Money lending should be stopped \\
\hline & Money laundering & Capital outflow is not under control \\
\hline & Corruption & $\begin{array}{l}\text { Perceived corruption and money laundering cannot afford to build confidence } \\
\text { on the monetary system }\end{array}$ \\
\hline \multirow{5}{*}{$\begin{array}{l}\text { Unequal Distribution } \\
\text { of Wealth }\end{array}$} & Disparities & The gap between rich and poor was widened \\
\hline & Less opportunities & The Syrian crisis has caused income inequality \\
\hline & Low productivity & Lack of opportunities for majority of degree holders \\
\hline & 然 & Shortage of skilled labor causing low productivity \\
\hline & dependence & Dependence on the primary sector was high \\
\hline \multirow{3}{*}{ Status Quo Ante } & Ante change & There are forces that do not want change \\
\hline & Compromise & People have compromised on the current state \\
\hline & Institutional stakes & Institutions have stakes in the current state \\
\hline \multirow{8}{*}{$\begin{array}{l}\text { Socio-Economic } \\
\text { Factors }\end{array}$} & Unemployment & Unskilled labor force has high unemployment rate \\
\hline & Inflation & Inflation has increased and interest rates are in double figures \\
\hline & ances & $\begin{array}{l}\text { The fall in oil prices caused a drop in foreign remittances from the Gulf countries } \\
\text { by about } 6 \%\end{array}$ \\
\hline & & The Syrian crisis is permanent and has been prevalent since 2011 \\
\hline & Syria & We have over 1.5 million Syrian refugees, putting a heavy burden on the economy \\
\hline & Infrastructure & Poor condition of the public transport system also causes regional disparities \\
\hline & & There is persistent load shedding preventing the industrial sector from working \\
\hline & Unrest & Strikes and public protests are common and can force the government to compromise \\
\hline
\end{tabular}

Figure 5. Thematic construct of Inherited Characteristics of the Economy 
term. For example, the statement "Large population was unable to protect their economic rights" can be represented by the term Economic Rights under the category Fairness in the group Trust Deficit. The fairness construct explains that the respondent feels that the economic crises during the COVID-19 pandemic may be accelerated by the feeling of lack of fairness in society.

Figure 5 shows the theme Inherited Characteristics of the Economy in terms of four latent constructs measured by 17 manifest terms (or codes) representing the impressions derived from the respective quotations. For example, the quotation "There are forces that do not want to change" is coded as Ante Change and derived through the latent construct Status Quo Ante. Similarly, "The gap between rich and poor was widened" is coded as Disparities. It is also an expansible concept and covers disparities in both income and regional disparities in the country.
The theme of Fiscal and Monetary Policies is shown in Figure 6. There are four latent constructs measured through 12 manifest terms. The construct of Indebtedness is a single item factor. FDI measures foreign direct investment and represses the impression of poor performance in this area.

\section{DESCRIPTIVE STATISTICS}

The terms used in the interviews are described using the word cloud and Term Frequency (TF) chart. These visual displays were obtained by using text mining algorithms in R-Programming language after preparing the text corpus of seven interview files taking through the punctuation removal, lower case conversion, digits and white space removals, and removing the stop words processes simultaneously. Term Document Matrix (TDM) and Document Term Matrices (DTM) were obtained respectively to further analyze

Theme of Fiscal \& Monetary Policies

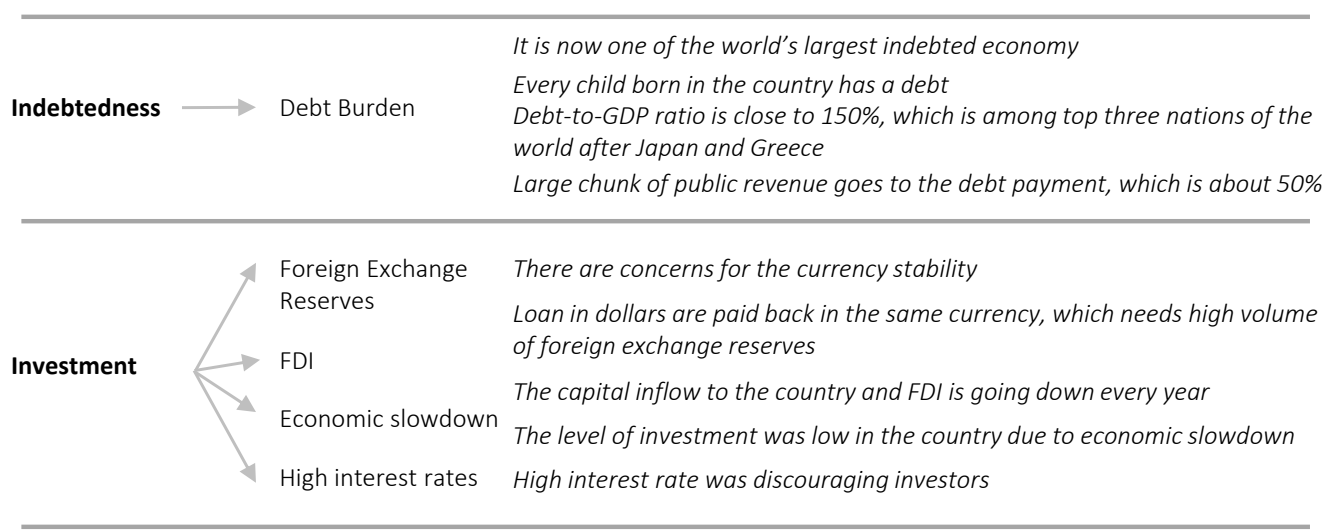

Public Spending $\longleftrightarrow \begin{aligned} & \text { Infrastructure } \\ & \text { building } \\ & \begin{array}{l}\text { Reducing } \\ \text { unemployment } \\ \text { Deficit financing }\end{array}\end{aligned} \quad \begin{aligned} & \text { High unemployment rate was due to less public spending } \\ & \text { increase the pressure on the budget deficit }\end{aligned}$

$\begin{array}{ll}\text { High Control } & \begin{array}{l}\text { More control means banks will not be able to extend internal loans to the } \\ \text { government for deficit financing }\end{array} \\ \begin{array}{l}\text { Foreign exchange } \\ \text { Restrictions }\end{array} & \begin{array}{l}\text { Strict monetary policy were adopted after the Arab Spring } \\ \text { Control on dollar withdrawal and transfer damages the confidence of } \\ \text { Highterest }\end{array} \\ \text { rates } & \begin{array}{l}\text { customers } \\ \text { Restricting Money } \\ \text { Supply }\end{array}\end{array}$

Figure 6. Thematic construct of Fiscal and Monetary Policies 


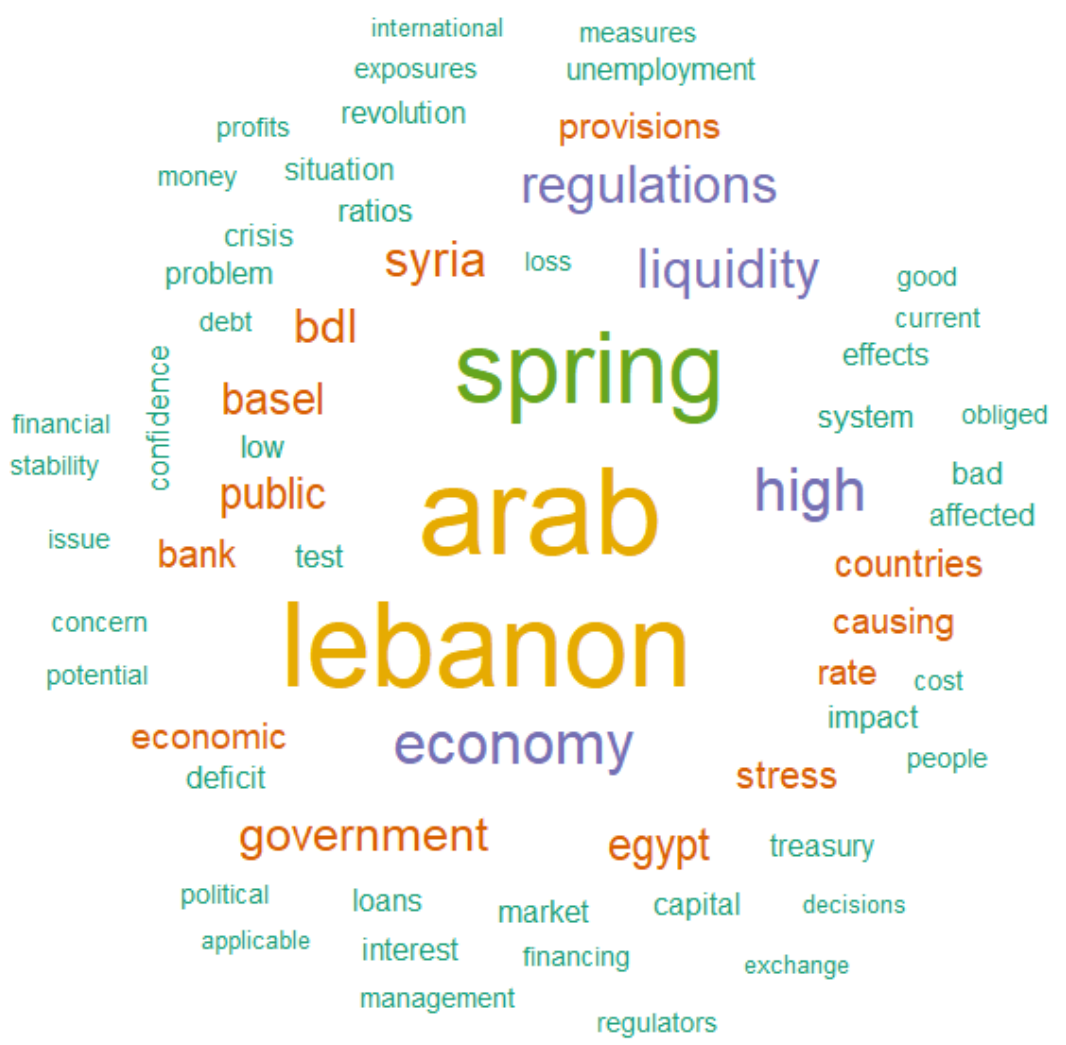

Figure 7. Interview data word cloud

the text. Bag of Words (BOW) was obtained to use it for further noise removal from the data before obtaining Words cloud (Figure 7) and histogram (Figure 8). Following is the output of [head ( )] function applied on the TDM, which provides first few rows (terms) from the matrix of terms X document(interview).

Word cloud in Figure 7 shows the impression about the contents taken up in the interviews. The term 'Lebanon' indicates the key context of the discussion, which is the country of Lebanon. Two terms - 'arab' and 'spring' - represent the composite term 'Arab Spring', which is technically separated in the text mining scheme. Likewise, the terms 'government, economy, economic, regulations, system, provisions, public, bdl (or BDL), stability, deficit, unemployment' are the impressions of the public policies, e.g. Fiscal and Monetary policies. The terms of crises, debt, basel, bank, test, treasury, capital, interest, markets, regulators, ratios, and rate are the impressions of banks' efforts to deal with the crises. Similarly, the terms like bad, low, deficit, concern, issue, problem, cost, political, and confidence are the impressions of trust deficit. Figure 8 shows the histogram of the word frequencies ranging between 5 and 40 .

\subsection{Risk analysis}

Risk analysis (Figure 9) of the interview text provides the banks' position with respect to the level of risk involved in terms of three moderators. The risk map allocates various interviews' quotes to the low, moderate, and high-risk zones, based on the probability of co-occurrence of impact and likelihood of the impression reflected through the quotes. The impact and likelihoods are measured on the scale from 1 to 5 , and the covariance value distributes the quote into low, moderate, and highrisk zones. The left bottom green shade shows the low risk zone, and they can be mitigated. It covers the concerns relating to the bank and monetary policy issues. They are considered low risk due to the degree of control in the hand of stakeholders, including banks and BDL. The middle yellow 


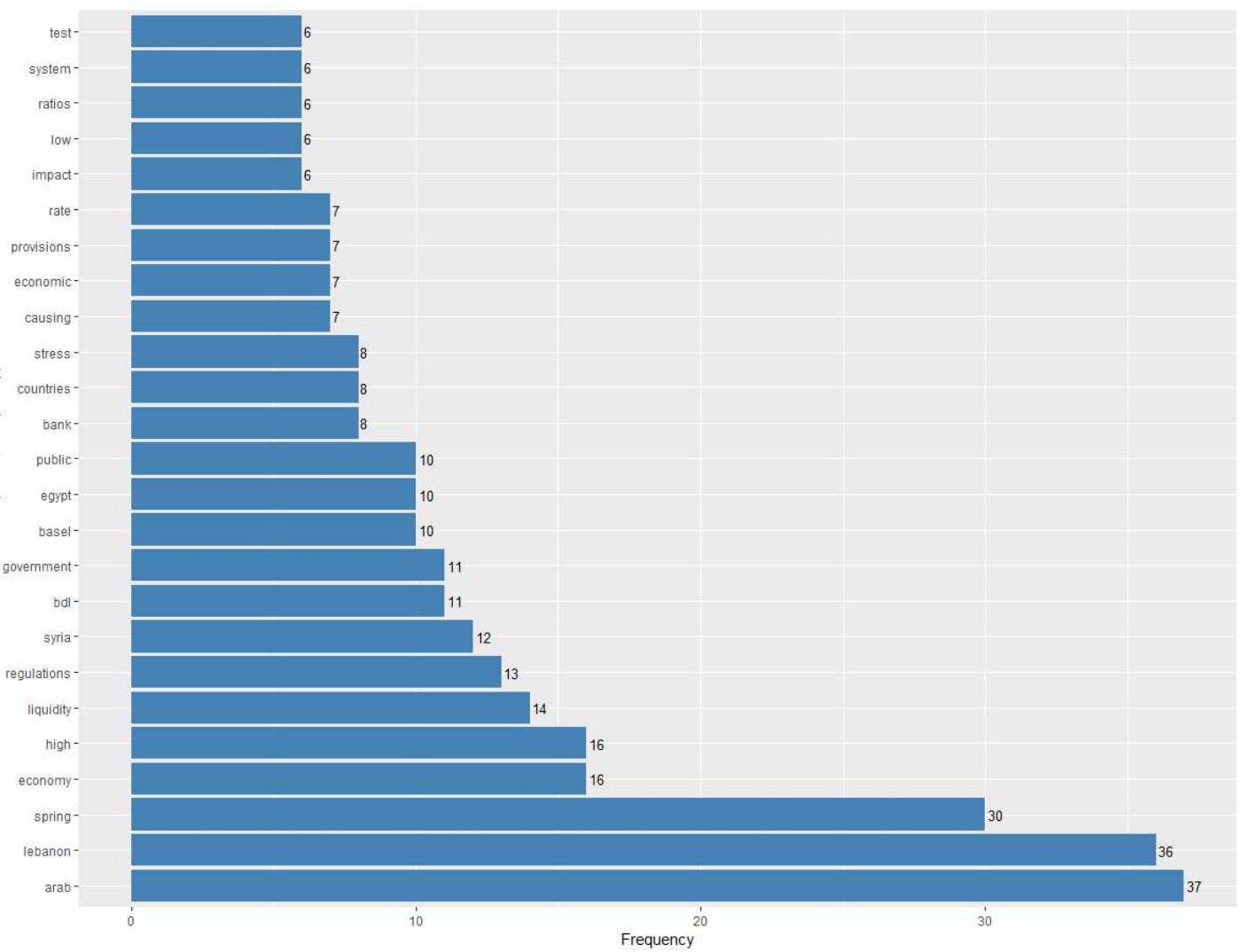

Figure 8. Histogram of terms used in the interview

shade shows the zone with moderate risk, and it cannot be solved in the short run. The long-term economic plans are required. Most of the concerns in this zone are related to the inherited character- istics of the economy. The concerns shown in the top right red zone are the high-risk factors. They are considered high risk, since they cannot be mitigated easily. These concerns are due to the trust

\begin{tabular}{|c|c|c|c|c|c|}
\hline \multicolumn{6}{|c|}{ Risk Matrix } \\
\hline 5 & $\begin{array}{l}\text { - structure of the } \\
\text { Lebanon is not } \\
\text { ready } \\
\text { - not enough buffer } \\
\text { to face crises }\end{array}$ & $\begin{array}{l}\text { - economic factors add } \\
\text { to the problem } \\
\text { - Institutions had stakes } \\
\text { in the current state } \\
\text { - the informal sector of } \\
\text { the economy }\end{array}$ & $\begin{array}{l}\text { - poor governance } \\
\text { - people doubt the } \\
\text { ability of government }\end{array}$ & $\begin{array}{l}\text { - policies are driven by } \\
\text { self-interests } \\
\text { - people had } \\
\text { compromised on } \\
\text { current state }\end{array}$ & $\begin{array}{l}\text { - incorrect information } \\
\text { - less job opportunities } \\
\text { creates anger } \\
\text { - conflict between haves } \\
\text { and haves not }\end{array}$ \\
\hline 4 & $\begin{array}{l}\text { - for economy, the } \\
\text { challenge is bigger } \\
\text { - inflation rate has } \\
\text { increased } \\
\text { - high cost of living }\end{array}$ & $\begin{array}{l}\text { - high debt payment } \\
\text { - falling oil prices }\end{array}$ & $\begin{array}{l}\text { - Syrian crises still exist } \\
\text { - the gap between rich } \\
\text { and poor } \\
\text { - problem of refugees }\end{array}$ & $\begin{array}{l}\text { - loss of trust is affecting } \\
\text { liquidity } \\
\text { - strikes and public } \\
\text { protests }\end{array}$ & $\begin{array}{l}\text { - tourism is down } \\
\text { - black market } \\
\text { - corruption } \\
\text { - money laundering }\end{array}$ \\
\hline 3 & $\begin{array}{l}\text { - bank subsidiaries } \\
\text { are manageable } \\
\text { - lesser operations } \\
\text { - decreasing } \\
\text { exposure } \\
\end{array}$ & $\begin{array}{l}\text { - debt-to-GDP ratio is } \\
\text { close to } 150 \% \\
\text { - interest rates were in } \\
\text { double figures }\end{array}$ & $\begin{array}{l}\text { - low productivity } \\
\text { - tourism is down }\end{array}$ & $\begin{array}{l}\text { - low level of investment } \\
\text { - poor infrastructure } \\
\text { - high unemployment } \\
\text { rate }\end{array}$ & $\begin{array}{l}\text { - state was incapable to } \\
\text { serve the people }\end{array}$ \\
\hline 2 & $\begin{array}{l}\text { - low financial impact } \\
\text { on bank } \\
\text { - cut on the new } \\
\text { lending }\end{array}$ & $\begin{array}{l}\text { - conservative plan } \\
\text { - precautionary } \\
\text { measures have taken }\end{array}$ & $\begin{array}{l}\text { there were forces who } \\
\text { did not want change }\end{array}$ & $\begin{array}{l}\text { - banks limitations to } \\
\text { fund budget deficit } \\
\text { - high direct tax }\end{array}$ & $\begin{array}{l}\text { - instable currency } \\
\text { - low public spending }\end{array}$ \\
\hline 1 & $\begin{array}{l}\text { - no loss but less } \\
\text { profits } \\
\text { - banks are cautious }\end{array}$ & $\begin{array}{l}\text { - strict monetary policy } \\
\text { - need monitoring the } \\
\text { liquidity flow }\end{array}$ & $\begin{array}{l}\text { - IMF } \\
\text { - confidence and } \\
\text { liquidity are the } \\
\text { concerns }\end{array}$ & - FDI is low & $\begin{array}{l}\text { - one of the world's } \\
\text { largest indebted } \\
\text { economy } \\
\text { - dependence on the } \\
\text { primary sector }\end{array}$ \\
\hline & 1 & 2 & 3 & 4 & 5 \\
\hline
\end{tabular}

Figure 9. Risk matrix 
deficit based on the past performance of the institutions. The high risk and moderate risk zones can be managed through effective fiscal and monetary measures in the short run and long-term economic measures in the long run.

\section{DISCUSSION}

This study was an effort to understand the potential of Lebanese banks to successfully survive the COVID-19 situation based on the experiences they have learned during and after the 2011 Arab Spring. The limited research on the topic, especially in terms of COVID-19 and Lebanon, has led to the inductive approach to develop the case for examination. The theoretical framework was then tested through the deductive methodology. The success of inductive approach depends on the strong rationale justifying the researcher's point of view. The rationale in this study was based on the conceptual framework (Figures 1 and 3) directing towards the study of similarity of the moderating factors between two cases (Arab Spring and COVID-19). The assumption was that the similarity of the moderators in the two cases can allow a researcher to hypothesize that the ability of the Lebanese banking sector to deal with the COVIDdriven economic crises is justified. Therefore, the aim of this study is to find the answers to the questions: Can Lebanese banks rely on the experience they have learned from the Arab Spring to deal with the COVID-19 crises? and Are moderators in the Arab Spring and COVID-19 models are aligned? The similarity of the moderators identified in the Arab Spring model and the COVID-19 allows hypothesizing that Lebanese banks have the ability to deal with the COVID-19 driven economic crises based on the experience from the Arab Spring.

\section{H1: The degree of trust deficit is the same during COVID-19 and the Arab Spring in Lebanon.}

The four constructs identified in the thematic diagram (Figure 7), Fairness, Integrity, Competence, and Reliability, confirm the prevailing impressions among bankers about the trust deficit in government performance during the Arab Spring and COVID-19. The impressions were that corruption, dishonesty, and failure to meet promises or to solve unemployment problems led to popular lack of confidence in the public sector's ability to perform in the crisis. The income disparities raised concerns about the success of public measures to deal with crises when strikes and public protests are common, increasing pressure on the government to compromise. The banking sector even finds difficulty in funding the government's fiscal deficit. These impressions are also clustered in the high-risk zone (Figure 9), showing the real threat to the government efforts in the COVID-19-led economic crisis. The conditions of trust deficit are similar during the Arab Spring and COVID-19, and bankers need to go an extra mile to deal with them.

H2: The nature of the economy in terms of inherited characteristics has not significantly changed over the last decade.

The Lebanese economy has inherited characteristics that pose a challenge to the government's efforts to deal with crises. The four constructs identified are the shadow economy, unequal distribution of wealth, status quo ante, and socio-economic factors. The informal sector of the economy coexists with the formal sector. Refugees from the Syrian war are adding to the crisis, with over 1.5 million considered as a permanent issue. Similarly, dependence on the primary sector and underdeveloped infrastructure have been seen for many years, even before the Arab Spring. With these conditions, fall in oil prices causes a reduction in foreign remittances. Most of these conditions are in the moderate-risk zone (Figure 9), which requires long-term strategies on the part of government to improve the infrastructure and bring social uplift to the underdeveloped sectors of the economy. These conditions are similar for both situations, and banks can take advantage of their experience in handling them.

H3: The conservative fiscal and monetary policies that helped during the Arab Spring are also in place to support combating the COVID19-driven economic challenge.

Fiscal and monetary policies are considered as low-risk factors in this study (Figure 9), as controllable factors that pose no serious threat in the COVID-19 crisis. The high debt burden is the re- 
sult of persistent deficit budgets financed by external loans. This also indicates the limitations of the BDL or commercial banks to finance the fiscal deficit. The Debt-to-GDP ratio is $150 \%$, third in the world after Japan and Greece, and a large portion of the public revenue goes to the debt repayments. The currency has generally remained stable, although showing a decline in value in recent years. The conservative monetary policy can be a good short-term measure, but it cannot succeed in the long run. The four constructs - indebtedness, investment, public spending, and conservativeness - are clearly linked to the level of fiscal and monetary policy impressions. Tax increases can also be difficult in a COVID-19 situation. Most of these conditions are the result of the Arab Spring experience, but can still be found in the case of COVID-19.

H4-H5: The economic conditions during COVID-19 are not very different from those during the
Arab Spring, and the Lebanese banking sector will be able to deal with the current economic threat.

Trust deficit, inherited characteristics of the economy and fiscal and monetary policies are the defining parameters of banking experience to be applied in the COVID-driven economic crisis. The discussion of these three moderating themes clearly gives the impression from the banking experts' viewpoints that they are common characteristics prevailing during both the Arab Spring and the current COVID-19 pandemic.

Key challenges faced during the study include a lack of availability of research data about the Lebanese banking sector's reaction to COVID-19. Data was gathered from seven senior bankers, but the study's findings could be improved by increasing the sample size, perhaps including quantitative survey data.

\section{CONCLUSION}

This study examines the ability of Lebanese banks to cope with the economic challenges posed by COVID-19 based on the experience gained during the economic turmoil of the Arab Spring. The analysis was carried out through a mixed method approach in the exploratory and confirmatory setting. The results indicate that there are similarities in the two events - the Arab Spring and COIVD-19. The study has confirmed that trust is a key indicator for government performance in any financial crisis $(\mathrm{H1})$, some conditions remain the same in any financial crisis (H2), conservative monetary and fiscal policy is needed to cope with the financial distress (H3), and the Lebanese banking sector is able to cope with the current situation as economic conditions are similar to those that existed during the Arab Spring, when banks managed to maintain their resilience $(\mathrm{H} 4-\mathrm{H} 5)$. The study has provided sufficient evidence to confirm that the experience of the Lebanese banking sector during the Arab Spring is a valuable asset for bankers, BDL, and government, which can be used to anticipate and handle the COVID-driven economic crisis. The policies must be developed based on the three key moderating factors identified: Trust Deficit, Inherited Characteristics of the Economy, and Fiscal and Monetary Policies. Most of these conditions are permanent in nature and need long-term reconsideration of the short-term policies. The COVID-19 pandemic prevails, and the resulting economic situations are only the crises currently perceived and may evolve differently from the Arab Spring crisis. The possibility of a V-shaped recovery is not out of question, and banks can take the advantage of a speedy recovery. The analysis provides opportunities for further research, and a possible extension of work could consider the phase after Beirut explosion and what the banking sector can do to cope with the negative consequences of this event.

\section{AUTHOR CONTRIBUTIONS}

Conceptualization: Rania Itani.

Data curation: Nawazish Mirza.

Formal analysis: Muhammad Azeem.

Investigation: Rania Itani. 
Methodology: Muhammad Azeem.

Project administration: Rania Itani.

Resources: Rania Itani.

Software: Muhammad Azeem.

Supervision: Nawazish Mirza.

Validation: Nawazish Mirza.

Visualization: Muhammad Azeem.

Writing - original draft: Rania Itani.

Writing - reviewing \& editing: Nawazish Mirza.

\section{REFERENCES}

1. Abraheem, N., Yahya, M. H., Muhammad, J., \& Ab Razak, N. H. (2020). Liquidity Creation and Competition in the Banking Industry Pre and Post Arab Spring in Mena Region. Academy of Accounting and Financial Studies Journal, 24(1), 1-20. Retrieved from https://www.questia.com/ library/journal/1G1-618468348/ liquidity-creation-and-competition-in-the-banking

2. Akhtaruzzaman, M., Boubaker, S., \& Sensoy, A. (2020). Financial contagion during COVID-19 crisis. Finance Research Letters, 101604. https://doi.org/10.1016/j. frl.2020.101604

3. Al-Awadhi, A. M., Al-Saifi, K., Al-Awadhi, A., \& Alhamadi, S (2020). Death and contagious infectious diseases: Impact of the COVID-19 virus on stock market returns. Journal of Behavioral and Experimental Finance, 27, 100326. https://doi.org/10.1016/j. jbef.2020.100326

4. Ali, M., Alam, N., \& Rizvi, S. A. R. (2020). Coronavirus (COVID-19) An epidemic or pandemic for financial markets. Journal of Behavioral and Experimental Finance, 27, 100341. https://doi. org/10.1016/j.jbef.2020.100341

5. Al-Rawashdeh, R., Al-Nawafleh, H., \& Al-Shboul, M. (2013). Understanding oil and mineral resources in a political economy context: the case of the Middle East and North Africa (MENA). Mineral Economics, 26(1-2), 13-28. https://doi.org/10.1007/s13563013-0035-3

6. Aras, B., \& Falk, R. (2016). Five years after the Arab Spring: a critical evaluation. Third World

Quarterly, 37(12), 2252-2258.

https://doi.org/10.1080/01436597. 2016.1224087

7. Boucekkine, R., Prieur, F., \& Puzon, K. (2016). On the timing of political regime changes in resource-dependent economies. European Economic Review, 85, 188-207. https://doi.org/10.1016/j. euroecorev.2016.02.016

8. Brown, R., \& Rocha, A. (2020). Entrepreneurial uncertainty during the Covid-19 crisis: Mapping the temporal dynamics of entrepreneurial finance. Journal of Business Venturing Insights, 14, e00174. https://doi.org/10.1016/j. jbvi.2020.e00174

9. Cohen, E. (2016). From Arab Spring to Economic Winterexamination of the relationship between politics and economics as evident in the Syrian civil war during 2011-2015. Journal of International Studies, 9(1), 9-26. https://doi.org/10.14254/20718330.2016/9-1/1

10. Colenda, C. C., Applegate, W. B., Reifler, B. V., \& Blazer, D. G. (2020). COVID-19: Financial Stress Test for Academic Medical Centers. Academic Medicine, 95(8), 1143-1145. Retrieved from https:// www.ncbi.nlm.nih.gov/pmc/articles/PMC7179061/

11. Devarajan, S., \& Ianchovichina, E. (2018). A broken social contract, not high inequality, led to the Arab spring. Review of Income and Wealth, 64, 5-25. Retrieved from https://www.researchgate.net/ publication/313848485_A_Broken_Social_Contract_Not_High_
Inequality_Led_to_the_Arab_ Spring

12. Echevarría, C. A., \& GarcíaEnríquez, J. (2019). The economic consequences of the Libyan Spring: A synthetic control analysis. Defence and Peace Economics, 30(5), 592-608. https:// doi.org/10.1080/10242694.2018.1 446241

13. El-Haddad, A. (2020). Redefining the social contract in the wake of the Arab Spring: The experiences of Egypt, Morocco and Tunisia. World Development, 127, 104774. https://doi.org/10.1016/j.worlddev.2019.104774

14. Falk, R. (2016). Rethinking the Arab Spring: uprisings, counterrevolution, chaos and global reverberations. Third World Quarterly, 37(12), 2322-2334. https://doi.org/10.1080/01436597. 2016.1218757

15. Farzanegan, M. R., Hassan, M., \& Badreldin, A. M. (2020). Economic liberalization in Egypt: A way to reduce the shadow economy? Journal of Policy Modeling, 42(2), 307-327. https://doi.org/10.1016/j.jpolmod.2019.09.008

16. Fisher, G., Stevenson, R., \& Burnell, D. (2020). Permission to hustle: Igniting entrepreneurship in an organization. Journal of Business Venturing Insights, 14, e00173. https://dx.doi. org/10.1016\%2Fj.jbvi.2020.e00173

17. Francis, N. N., \& Pegg, S. (2020). Socially distanced school-based nutrition program feeding under COVID 19 in the rural Niger Delta. The Extractive Industries 
and Society, 7(2), 576-579.

https://dx.doi.org/10.1016\%2Fj. exis.2020.04.007

18. Gaur, D., \& Mohapatra, D. R. (2020). Non-performing Assets and Profitability: Case of Indian Banking Sector. Vision: The Journal of Business Perspective, 0972262920914106. https://doi. org/10.1177/0972262920914106

19. Gibson, C. W. (2020). Determinants of state spending patterns in Arab League member states: A post-Arab Spring analysis, 1996-2014. International Journal of Politics, Culture, and Society, 33(1), 23-48. https://doi. org/10.1007/s10767-018-9293-y

20. Goffman, E. (2020). In the wake of COVID-19, is glocalization our sustainability future? Sustainability: Science, Practice and Policy, 16(1), 48-52. https:// doi.org/10.1080/15487733.2020.1 765678

21. Gopichandran, V., Subramaniam, S., \& Kalsingh, M. J. (2020). COVID-19 pandemic: A litmus test of trust in the health system. Asian Bioethics Review, 12, 213221. https://doi.org/10.1007/ s41649-020-00122-6

22. Heimberger, P. (2020). Potential Output, EU Fiscal Surveillance and the COVID-19 Shock. Intereconomics, 55(3), 167-174. https://doi.org/10.1007/s10272020-0895-Z

23. Helmy, H. E. (2013). The impact of corruption on FDI: is MENA an exception? International Review of Applied Economics, 27(4), 491-514. https://doi.org/10.1080/02692171. 2012.752445

24. Hernandez, J. A., Kang, S. H., Shahzad, S. J. H., \& Yoon, S. M. (2020). Spillovers and diversification potential of bank equity returns from developed and emerging America. The North American Journal of Economics and Finance, 54, 101219. https://doi.org/10.1016/j. najef.2020.101219

25. Iacus, S. M., Natale, F., Santamaria, C., Spyratos, S., \& Vespe, M. (2020). Estimating and projecting air passenger traffic during the COVID-19 coronavirus outbreak and its socio-economic impact. Safety Science, 129, 104791. https://doi.org/10.1016/j. ssci.2020.104791

26. Kadoya, Y., Khan, M. S. R., \& Yamane, T. (2020). Government's Stimulus Program to Boost Consumer Spending: A Case of Discount Shopping Coupon Scheme in Japan. Sustainability, 12(9), 3906. https://doi. org/10.3390/su12093906

27. Kireçci, M. A. (2012). Relating Turkey to the Middle East and North Africa: Arab Spring and the Turkish Experience. Bilig, 63, 111134. Retrieved from http://www. acarindex.com/dosyalar/makale/ acarindex-1423873014.pdf

28. Krippendorff, K. (2004). Content Analysis: An introduction to its methodology (2nd ed.) (p. 122). Sage Publication. Retrieved from https://usu.instructure.com/ files/70315935/download

29. Lafferty, G., \& Youssef, J. (2015). Beyond the Arab Spring: Evaluating Libya's long-term tourism prospects. Tourism Management Perspectives, 14, 5562. https://doi.org/doi:10.1016/j. tmp.2015.03.002

30. Lightfoot, M. (2015). Education reform for the knowledge economy in the state of Sangon. Compare: A Journal of Comparative and International Education, 45(5), 705-726. https:// doi.org/10.1080/03057925.2014. 916970

31. Liu, X., \& Chang, Y. C. (2020). An emergency responding mechanism for cruise epidemic prevention - taking COVID-19 as an example. Marine Policy, 119, 104093. https://doi.org/10.1016/j. marpol.2020.104093

32. Maher, C. S., Hoang, T., \& Hindery, A. (2020). Fiscal Responses to COVID-19: Evidence from Local Governments and Nonprofits. Public Administration Review, 80(4). https://doi.org/10.1111/ puar.13238

33. Malec, K., Gouda, S., Kuzmenko, E., Soleimani, D., Rezbová,
H., \& Šánová, P. (2016). GDP Development and Employment in Egypt (2000-2013). International Journal of Economics and Financial Issues, 6(1), 199-206. Retrieved from https://www.econjournals. com/index.php/ijefi/article/ view/1577

34. Matta, S., Appleton, S., \& Bleaney, M. (2019). The impact of the Arab Spring on the Tunisian economy. The World Bank Economic Review, 33(1), 231-258. https://doi. org/10.1093/wber/lhw059

35. Merkley, E., Bridgman, A., Loewen, P. J., Owen, T., Ruths, D., \& Zhilin, O. (2020). A Rare Moment of Cross-Partisan Consensus: Elite and Public Response to the COVID-19 Pandemic in Canada. Canadian Journal of Political Science/Revue canadienne de science politique, 53(2), 1-8. https://doi.org/10.1017/ S0008423920000311

36. Morakabati, Y. (2020). A question of confidence. Is tourism as vulnerable to civil unrest as we think? A comparative analysis of the impact of Arab Spring on total reserves and tourism receipts. International Journal of Tourism Research, 22(2), 252-265. https:// doi.org/10.1002/jtr.2333

37. Nzediegwu, C., \& Chang, S. X. (2020). Improper solid waste management increases potential for COVID-19 spread in developing countries. Resources, Conservation, and Recycling, 161, 104947. https:// dx.doi.org/10.1016\%2Fj.resconrec.2020.104947

38. Qian, Y., \& Fan, W. (2020). Who Loses Income During the COVID-19 Outbreak? Evidence from China. Research in Social Stratification and Mobility, 68 , 100522. Retrieved from https:// pesquisa.bvsalud.org/globalliterature-on-novel-coronavirus2019-ncov/resource/en/covidwho-597305

39. Rizvi, S. K. A., Mirza, N., Naqvi, B., \& Rahat, B. (2020). Covid-19 and asset management in EU: a preliminary assessment of performance and investment styles. Journal of Asset 
Management, 21, 281-291. https:// doi.org/10.1057/s41260-02000172-3

40. Rougier, E. (2016). "Fire in Cairo": Authoritarian-redistributive social contracts, structural change, and the Arab spring. World Development, 78, 148-171. https://doi.org/10.1016/j.worlddev.2015.10.005

41. Saha, J., Barman, B. B., \& Chouhan, P. (2020). Lockdown for COVID-19 and its impact on pupil mobility in India: an analysis of the COVID-19 Community Mobility Reports, 2020. Children and Youth Services Review, 116, 105160. https://doi.org/10.1016/j. childyouth.2020.105160

42. Sharma, G. D., Talan, G., Srivastava, M., Yadav, A., \& Chopra, R. (2020). A qualitative enquiry into strategic and operational responses to Covid-19 challenges in South Asia. Journal of Public Affairs, 20(4), e2195. https://doi.org/10.1002/pa.2195

43. Shehadeh, L., \& Lai, Q. (2020). Political Economy of Exclusion: State-Based Incitement of Intolerance as a Distraction from a Downturn in the Economy. Politics and Religion, 1-23. https://doi.org/10.1017/ S1755048320000206

44. Sheth, J. (2020). Impact of Covid-19 on Consumer Behavior: Will the Old Habits Return or Die? Journal of Business Research, 117,
280-283. https://doi.org/10.1016/j. jbusres.2020.05.059

45. Sigala, M. (2020). Tourism and COVID-19: impacts and implications for advancing and resetting industry and research. Journal of Business Research, 117, 312-321. https://doi.org/10.1016/j. jbusres.2020.06.015

46. Singh, M. K., \& Neog, Y. (2020). Contagion effect of COVID-19 outbreak: Another recipe for disaster on Indian economy. Journal of Public Affairs, 20(4), e2171. https://doi.org/10.1002/ pa.2171

47. Talbot, D., \& Ordonez-Ponce, E. (2020). Canadian banks' responses to COVID-19: a strategic positioning analysis. Journal of Sustainable Finance \& Investment, 1-8. https://doi.org/10.1080/20430 795.2020.1771982

48. Tran, B. X., Nguyen, H. T., Pham, H. Q., Le, H. T., Vu, G. T., Latkin, C. A., Ho, C. S., \& Ho, R. C. (2020). Capacity of local authority and community on epidemic response in Vietnam: Implication for COVID-19 preparedness. Safety Science, 103, 104867. https://doi.org/10.1016/j. ssci.2020.104867

49. Velasco, R. B., Carpanese, I., Interian, R., Paulo Neto, O. C., \& Ribeiro, C. C. (2020). A decision support system for fraud detection in public procurement. International Transactions in
Operational Research, 28(1), 27-47. https://doi.org/10.1111/itor.12811

50. Wells, P., Abouarghoub, W., Pettit, S., \& Beresford, A. (2020). A socio-technical transitions perspective for assessing future sustainability following the COVID-19 pandemic. Sustainability: Science, Practice and Policy, 16(1), 29-36. https:// doi.org/10.1080/15487733.2020.1 763002

51. Wójcik, D., \& Ioannou, S. (2020). COVID-19 and Finance: Market Developments So Far and Potential Impacts on the Financial Sector and Centres. Tijdschrift voor economische en sociale geografie, 111(3), 387-400. https://doi. org/10.1111/tesg. 12434

52. Wong, C. M. L., \& Jensen, O. (2020). The paradox of trust: perceived risk and public compliance during the COVID-19 pandemic in Singapore. Journal of Risk Research, 23(7-8), 1-10. https://doi.org/10.1080/13669877. 2020.1756386

53. Zenker, S., \& Kock, F. (2020). The coronavirus pandemic - A critical discussion of a tourism research agenda. Tourism Management, 81, 104164. https://doi.org/10.1016/j. tourman.2020.104164

54. Zhang, D., Hu, M., \& Ji, Q. (2020) Financial markets under the global pandemic of COVID-19. Finance Research Letters, 36, 101528. https://doi.org/10.1016/j. frl.2020.101528 